\title{
PENANGANAN STICKY DAN PITCH SECARA ENZIMATIS PADA DAUR ULANG KERTAS BEKAS
}

\author{
Nina Elyani a , Jenni R ${ }^{\text {a, }}$, Sonny K. Wirawan a, $\mathrm{Cucu}^{\text {a }}$ \\ ${ }^{a}$ Balai Besar Pulp dan Kertas \\ Jl. Raya Dayeuhkolot 132 Bandung 40258 Tlp. (022) 5202980 Fax. (022) 5202871 \\ e-mail: bbpk@bbpk.go.id \\ Diterima : 02 Maret 2011, Revisi akhir : 27 Mei 2011
}

ENZYMATIC HANDLING OF STICKY AND PITCH IN THE WASTE-PAPER

\begin{abstract}
Sticky and pitch are constraint in the recycling process of coated print paper often occured. Research of sticky and pitch handling has been done for coated paper recycling process by applying lipase at 0.1 and $0.5 \%, \mathrm{pH}$ 6-7 and the temperature of $70-80^{\circ} \mathrm{C}$ for 30 minutes. The addition of conventional surfactant at 0.1 and $0.5 \%$ by weight of dry pulp is used as comparison. The results showed that the handling of sticky and pitch enzymatically produces paper with brightness, opacity, dirt contain and tensile index better than that of using the conventional surfactant.
\end{abstract}

Key words : waste paper, sticky, pitch, lipase, surfactants

\begin{abstract}
ABSTRAK
Sticky dan pitch pada proses daur ulang kertas cetak salut merupakan kendala yang sering terjadi karena mengganggu peralatan pembuatan kertas. Pada penelitian penanganan sticky dan pitch ini telah dilakukan pada proses daur ulang kertas cetak salut bekas dengan menggunakan lipase sebesar 0,1 $0,5 \%, \mathrm{pH} 6-7$ dan suhu sekitar $70-80^{\circ} \mathrm{C}$ selama 30 menit. Sebagai pembanding juga dilakukan penambahan surfaktan sebesar $0,1 \%$ - 0,5\% terhadap berat kering pulp. Hasil penelitian menunjukkan bahwa penanganan sticky dan pitch secara enzimatis menghasilkan derajat putih, opasitas, noda dan indeks tarik yang lebih baik dibandingkan secara konvensional yang menggunakan surfaktan.
\end{abstract}

Kata kunci : kertas bekas, sticky, pitch, lipase surfaktan

\section{PENDAHULUAN}

Salah satu masalah yang sering terjadi pada proses daur ulang kertas bekas khususnya untuk keras salutadalah terdapatnya kontaminan sticky dan pitch. Sticky dan pitch pada kertas bekas merupakan bahan yang sukar larut dalam air. Adanya sticky dan pitch pada pengolahan kertas bekas mengakibatkan masalah pada peralatan penyediaan stok dan di mesin kertas (Allen, 2002 and Kocurek, 1992). Di industri pulp dan kertas pada umumnya penanganan sticky dan pitch pada kertas dilakukan secara fisika dan kimia. Secara fisika yaitu dengan melakukan proses penguraian serat, proses pencucian serat dan proses penyaringan serat, sedangkan secara kimia yaitu dengan menambahkan bahan kimia seperti dispersan, talk, alum dan polimer (Blazey, et al., 2003 and Thorn and Che, 2009).

Dalam mendukung program pemerintah yang berwawasan lingkungan di industri pulp dan kertas, maka perlu adanya reduksi pemakaian bahan kimia yang akan mencemari. Penelitian ini difokuskan pada penanganan sticky dan pitch pada kertas bekas secara enzimatis, sehingga diharapkan serat daur ulang yang diperoleh dapat digunakan kembali sebagai bahan baku kertas yang berkualitas baik (Biermann, 1999). Sebagai pembanding digunakan juga bahan kimia yaitu surfaktan untuk menangani sticky dan pitch ini dapat terjadi. 
Sticky adalah sejenis kontaminan yang memiliki sifat-sifat khusus dan dapat menimbulkan permasalahan pada proses pembuatan kertas. Salah satu sifat penting dari partikel-partikel sticky adalah sifat hidrofobik yang alami.

Deposit terjadi karena partikel-partikel tersebut terlepas dari fasa air dan saling tarik menarik atau menempel pada bahan yang permukaannya bersifat hidrofobik seperti press felt dan roll. Sticky seringkali memiliki densiti yang hampir sama dengan air dan oleh karena itu sulit untuk dikendalikan atau dihilangkan (Biermann, 1999 and Thorn and Che, 2009).

Pitch merupakan senyawa berbentuk resin yang umumnya terdapat dalam pulp asli. Pitch berasal dari pulp kimia dan mekanis kayu, berupa rosin dan ekstraktif yang bersifat tidak larut dan tidak suka air atau hidrofobik. Pitch sering juga disebut sebagai resin kayu yang dilepas dari serat pada waktu proses penggilingan dan cenderung berakumulasi membentuk suspensi koloid dari partikel yang bermuatan negatif (Sithole \& Allen, 2003 and Vorcoe, et al., 2005). Partikel-partikel ini akan menyebabkan masalah karena akan menyumbat wire pada mesin kertas serta akan membentuk gumpalan berwana gelap sehingga dapat menimbulkan noda dan lubanglubang transparan pada kertas yang dihasilkan (Back, 1991, Biermann, 1999 and Kocurek, 1992)

Sebagian hati kayu dan kayu teras dari semua species kayujarum dan kayudaun mengandung sejumlah kecil senyawa-senyawa organik oleofilik yang sebagian besar bersifat non polar dengan kelarutan dalam air rendah. Senyawa ini biasanya dinyatakan resin kayu yang umumnya disebut sebagai pitch. Resin kayu dibagi dua kelas yaitu resin canal dan resin parenchyma. Resin kayu meliputi oleoresin yang terdiri dari terpen, asam resin dan bahan-bahan yang bersifat netral, serta lemak resin yang terdiri dari asam lemak dan unsaponification. (Back, E.L., \& Allen, L H, 2002).

Beberapa upaya dapat dilakukan untuk mengatasi masalah sticky dan pitch ini, baik pada proses pembuatan pulp di pabrik maupun pada proses pembuatan kertas di pabrik kertas. Pada prinsipnya ada dua cara yang umum dilakukan untuk mengendalikanya yaitu mencegah pembentukkan sticky dan pitch atau dengan menjaga pitch tetap dalam kondisi terdispersi yaitu dengan dugunakan polimer dispersan larut air dan bahan aktif permukaan (surfaktan). Dari berbagai jenis surfaktan yang ada, jenis nonionik dilaporkan paling efektif dalam menjaga stabilitas dispersi koloid pitch (Thorn and Che, 2009). Selain itu penanganan sticky dan pitch dapat dilakukan secara teknologi enzim yaitu dengan menggunakan lipase (Zhang and Irie et al., 1990). Lipase dapat mendegradasi trigliserida sehingga dapat mengurangi down time dan penurunan frekuensi pembersihan, mengurangi noda dan menaikkan kekuatan kertas yang dihasilkan (Fischer \& Messner, 1992, Johansson et al., 1998 and Gurnagul, et al., 1992).

\section{BAHAN DAN METODE}

\section{Bahan}

Bahan baku yang digunakan dalam percobaan adalah kertas cetak salut bekas $100 \%$ dan enzim yang digunakan adalah lipase sebasar $0,1 \%$ dan $0,5 \%$. Sebagai pembanding digunakan surfaktan sebesar $0,1 \%$ dan $0,5 \%$.

\section{Metode}

Kertas cetak salut bekas dengan konsistensi 4\% diuraikan dengan menggunakan hydropulper sampai diperoleh derajat giling 300 CSF. Setelah derajat giling tercapai, bubur kertas dipanaskan sampai suhu $70-80^{\circ} \mathrm{C}$ kemudian ditambahkan lipase sebesar $0,1 \%$ dan $0,5 \%$ pada $\mathrm{pH}$ sekitar $6-7$ dan biarkan bereaksi selama 30 menit untuk memberikan kesempatan enzim mendegradasi pitch dan sticky yang berada di permukaan serat. Kemudian dengan cepat suhu dinaikkan hingga diatas $90^{\circ} \mathrm{C}$ dan pada suhu tersebut dibiarkan selam 5 menit untuk menghentikan aktivitas enzim. Stok diencerkan sampai dengan konsistensi $1 \%$ kemudian dilakukan proses pencucian hingga $\mathrm{pH}$ netral. Pulp hasil pencucian dibuat lembaran tangan dengan gramatur $60 \mathrm{~g} / \mathrm{m}^{2}$. Kemudian dilakukan proses pengepresan dan pengeringan. Lembaran yang diperoleh kemudian dikondisikan di dalam ruang kondisi dengan suhu $23 \pm 1^{\circ} \mathrm{C}$ dan $\mathrm{RH}$ $50 \pm 2 \%$ selama 24 jam. Sebagai pembanding dilakukan juga pembuatan lembaran secara konvensional dengan menggunakan surfaktan sebesar $0,1 \%$ dan $0,5 \%$. Lembaran kertas yang diperoleh dilakukan pengujian sifat optik dan kekuatan yang meliputi derajat putih, opasitas, noda dan indeks tarik. Diagram alir percobaan dapat dilihat pada Gambar 1. 


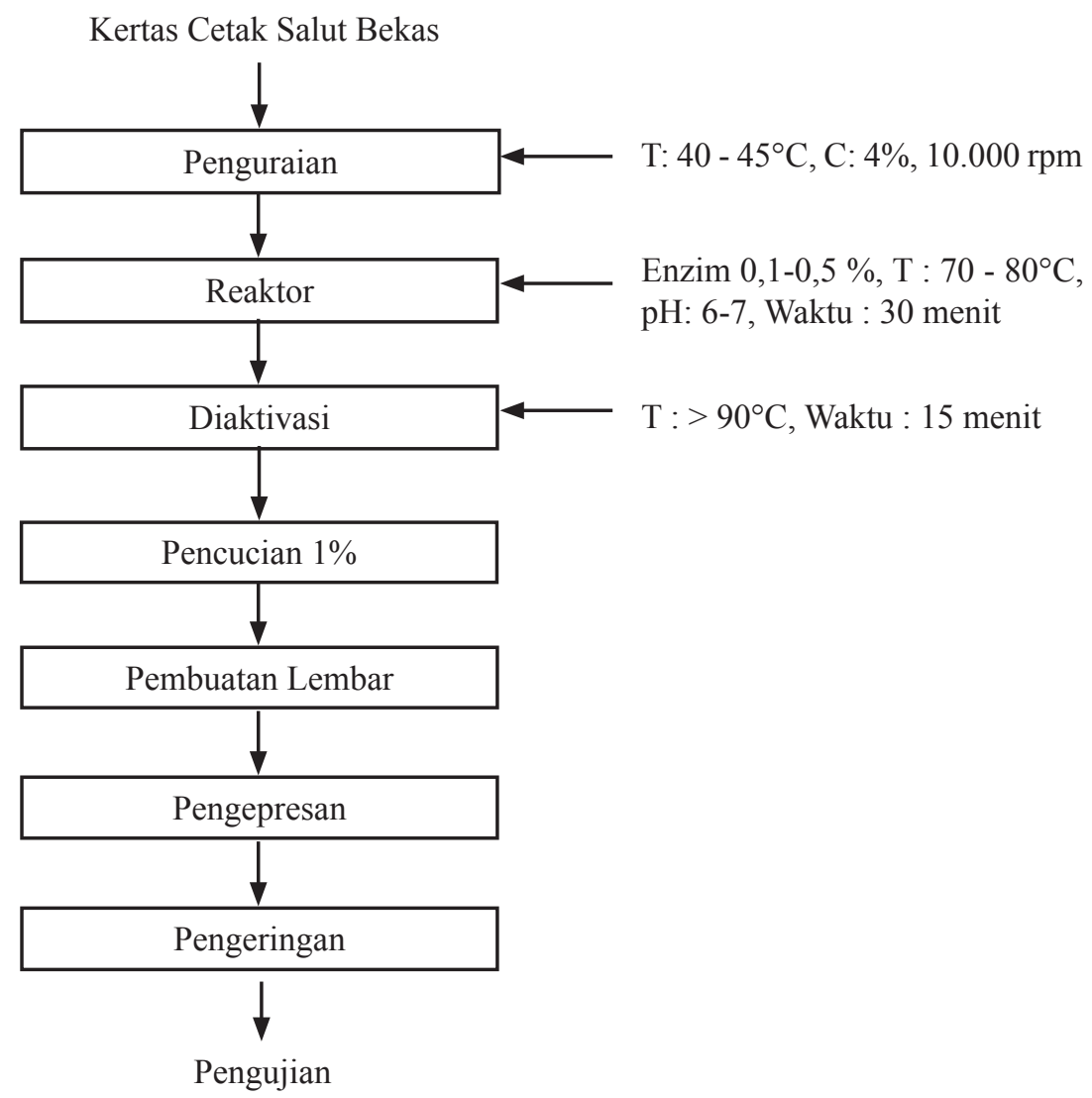

Gambar 1. Diagram Alir Percobaan

\section{HASIL DAN PEMBAHASAN}

Sifat lembaran kertas hasil proses pemisahan sticky dan pitch baik dengan menggunakan enzim ataupun surfaktan pada kertas cetak salut, dapat dilihat pada Gambar 2 sampai dengan Gambar 5.

\section{Derajat Putih}

Penggunaan enzim sebesar 0,1 dan $0,5 \%$ pada proses pemisahan sticky dan pitch pada kertas cetak salut bekas dapat meningkatkan derajat putih sekitar 2 dan 9 poin dibandingkan dengan nilai derajat putih tanpa penambahan enzim. Nilai derajat putih yang paling tinggi diperoleh pada penambahan enzim sebesar $0,5 \%$ yaitu $49 \%$ ISO. Demikian juga terhadap hasil pemisahan sticky dan pitch dengan penggunaan surfaktan sebesar 0,1 dan $0,5 \%$ nilai derajat putih meningkat hanya sekitar 1 dan 3 poin. Kerja enzim sangat dipengaruhi oleh kondisi inkubasi dan aktivitasnya.

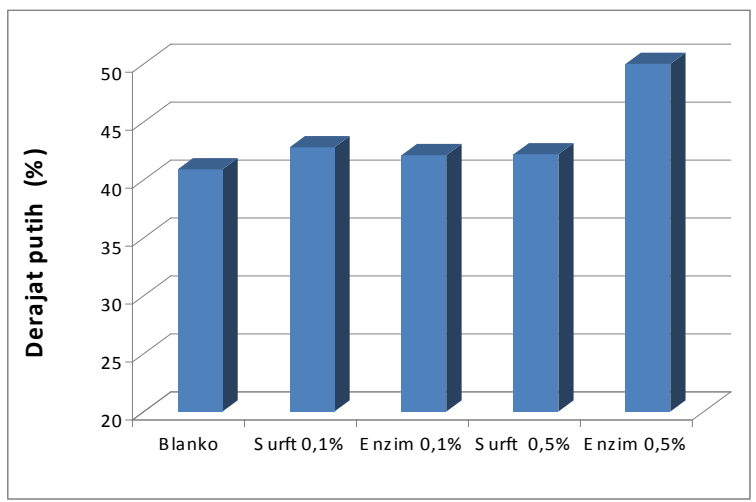

Gambar 2. Derajat Putih

\section{Opasitas}

Opasitas merupakan sifat optik yang paling penting terutama untuk kertas cetak. Pengukuran nilai opasitas didasarkan pada besarnya koefisien penghamburan dan penyerapan cahaya yang dilewatkan pada kertas menggunakan reflektor yang melewati sinar dengan panjang gelombang tertentu. 
Kertas dengan opasitas yang tinggi tidak akan membentuk bayangan hasil cetakan pada permukaan sebelahannya. Nilai opasitas ini dipengaruhiantara lain oleh gramatur, penggilingan, formasi lembaran, jumlah dan jenis bahan pengisi, jumlah fines serta jenis serat. Kenaikan gramatur lembaran akan berpengaruh terhadap kenaikan opasitas lembaran, sedangkan berkurangnya fraksi fines yang memiliki luas spesifik lebih besar dapat menyebabkan turunnya kemampuan penyebaran cahaya oleh lembaran sehingga dapat menurunkan opasitas lembaran. Adapun hasil pengujian opasitas lembaran yang diuji dapat dilihat pada Gambar 2 . Nilai opasitas tertinggi diperoleh pada penggunaan enzim sebesar $0,5 \%$ yaitu diperoleh 99,37\%, sedangkan dengan penambahan surfaktan sebesar $0,5 \%$ nilai opasitasnya adalah $98,97 \%$.

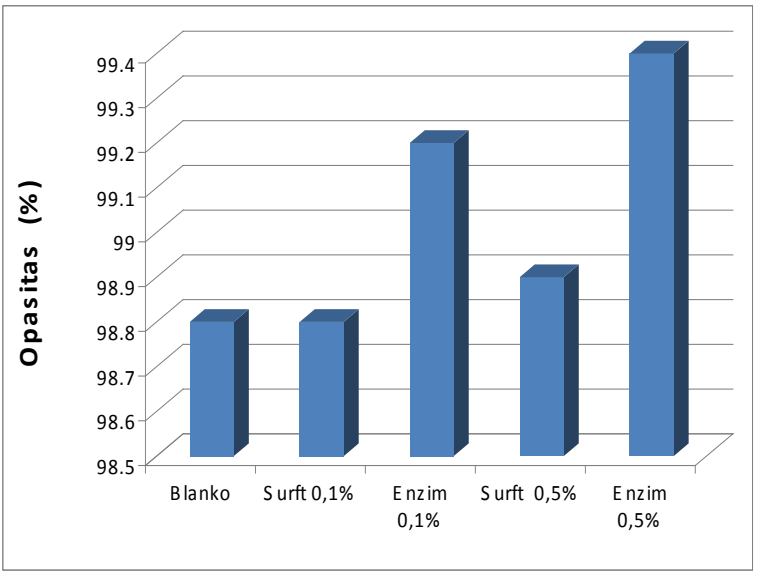

Gambar 3. Opasitas

\section{Noda}

Menurut SNI 0697-2009 tentang cara uji noda pada lembaran pulp kertas dan karton, noda didefinisikan sebagai benda asing yang terdapat pada lembaran pulp, kertas atau karton yang saat diperiksa dengan cahaya pantul tampak kontras dan berukuran lebih besar atau sama dengan $0,04 \mathrm{~mm}^{2}$. Luas hitam setara adalah luas sebuah standar noda hitam bulat diatas dasar putih yang memberikan kesan pandangan sama dengan noda yang terdapat pada lembaran uji.

Faktor yang mempengaruhi jumlah noda pada lembaran yang diuji diantaranya keanekaragaman bahan baku yang digunakan, jenis dan ukuran tinta, dosis enzim maupun bahan kimia yang ditambahkan, aktivitas enzim, serta efektivitas proses pencucian meliputi kondisi proses seperti konsistensi, suhu, waktu retensi.
Menurut sumber lain, noda didefinisikan sebagai benda-benda asing yang terdapat pada lembaran, berwarna lain dan mempunyai luas hitam setara (equivalent black area) minimal $0,04 \mathrm{~mm}^{2}$. Luas hitam setara adalah luas sebuah standar noda hitam bulat di atas dasar putih yang memberikan kesan pandangan sama dengan noda yang terdapat pada lembaran. Jumlah noda pada lembaran merupakan salah satu indikator dari efektifitas proses deinking. Setelah adanya tindakan washing ataupun flotasi sehingga dapat memisahkan noda dari lembaran. Ukuran noda yang lebih rendah dari ukuran minimal luas hitam setarayakni $<0,04 \mathrm{~mm}^{2}$ akan luputdariperhitungan karena tidak terdeteksi. Hasil pengujian noda lembaran yang diuji dapat dilihat pada Gambar 3 . Nilai noda terendah diperoleh pada penggunaan enzim sebesar $0,5 \%$ yaitu diperoleh $800 \mathrm{~mm}^{2} / \mathrm{m}^{2}$, sedangkan dengan penambahan surfaktan sebesar $0,5 \%$ nilai noda bertambah banyak dibandingkan dengan penambahan enzim $0,5 \%$, yaitu 1400 $\mathrm{mm}^{2} / \mathrm{m}^{2}$.

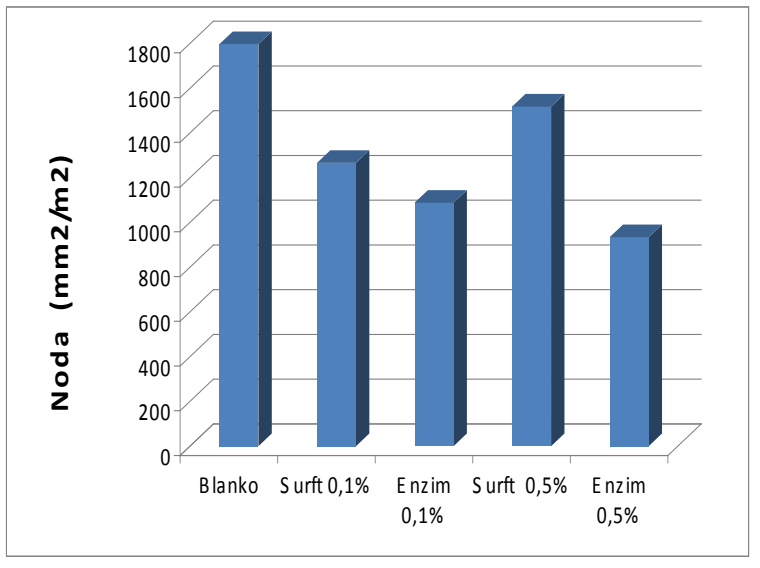

Gambar 4. Noda

\section{Indeks tarik}

Ketahanan tarik (tensile) adalah gaya tarik maksimum persatuan lebar yang di butuhkan untuk memutuskan kertas. Menurut SNI 140437-1998 tentang cara uji ketahanan tarik kertas dan karton, ketahanan tarik di definisikan sebagai gaya tarik yang bekerja pada kedua ujung kertas dan karton, di ukur pada kondisi standar. Faktor-faktor yang mempengaruhi ketahanan tarik (tensile strength) adalah jumlah dan kualitas ikatan antar serat, penggilingan, panjang serat, bahan pengisi (filler) dan fines. Sedangkan semakin panjang serat, ketahanan tariknya semakin tinggi juga, apabila kandungan 
bahan pengisi dan fines yang cukup tinggi maka ketahanan tariknya cenderung menurun, karena di akibatkan ikatan antar serat menjadi berkurang. Hasil pengujian indeks tarik lembaran yang diuji dapat dilihat pada grafik dibawah ini. Nilai indeks tarik tertinggi diperoleh pada penggunaan enzim sebesar $0,5 \%$ yaitu diperoleh $26,8 \mathrm{Nm} / \mathrm{g}$, sedangkan dengan penambahan surfaktan sebesar $0,5 \%$, nilai indeks tariknya yaitu $24,8 \mathrm{Nm} / \mathrm{g}$.

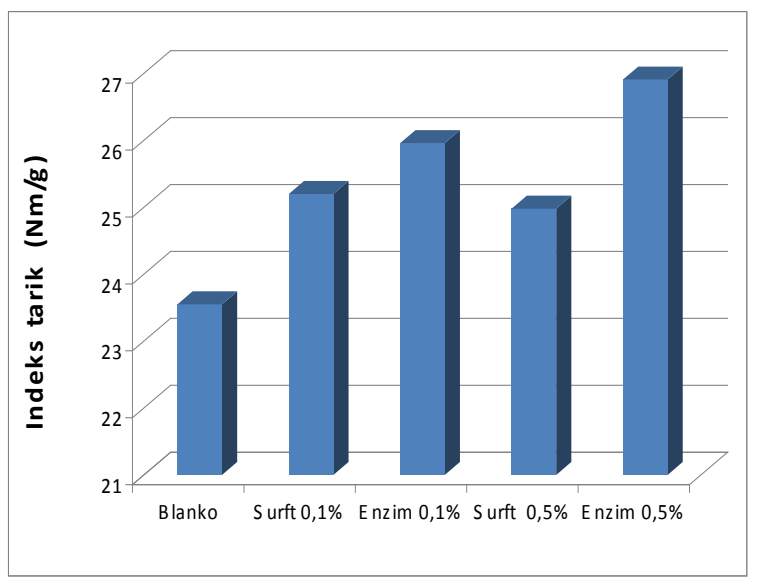

Gambar 5. Indeks Tarik

\section{KESIMPULAN}

Hasil percobaan dapat disimpulkan sebagai berikut :

1. Penggunaan enzim sebesar 0,1 dan $0,5 \%$ pada proses pemisahan sticky dan pitch pada kertas cetak salut bekas dapat meningkatkan derajat putih sekitar 2 dan 9 poin. Sedangkan dengan penggunaan surfaktan sebasar 0,1 dan $0,5 \%$ nilai derajat putih meningkat hanya sekitar 1 dan 3 poin.

2. Nilai opasitas tertinggi diperoleh pada penggunaan enzim sebesar $0,5 \%$ yaitu diperoleh sekitar 99,37\%, sedangkan dengan penambahan surfaktan sebesar $0,5 \%$ nilai opasitasnya adalah sekitar $98,97 \%$.

3. Nilainodaterendah diperolehpada penggunaan enzim sebesar $0,5 \%$ yaitu diperoleh 800 $\mathrm{mm}^{2} / \mathrm{m}^{2}$, sedangkan dengan penambahan surfaktan sebesar $0,5 \%$ nilai noda bertambah banyak dibandingkan dengan penambahan enzim $0,5 \%$, yaitu adalah $1400 \mathrm{~mm}^{2} / \mathrm{m}^{2}$.

4. Nilai indeks tarik tertinggi diperoleh pada penggunaan enzim sebesar $0,5 \%$ yaitu diperoleh $26,8 \mathrm{Nm} / \mathrm{g}$, sedangkan dengan penambahan surfaktan sebesar $0,5 \%$ nilai indeks tariknya yaitu $24,8 \mathrm{Nm} / \mathrm{g}$.

\section{DAFTAR PUSTAKA}

Allen, L. H., 2002, Deposition Synergy Between Mechanical and Deinked Pulps, TAPPI Technology Summit Proceedings.

Back, E. L., 1991, Paper-to-paper and paper-tometal friction, International Paper Physics Conference, Kona, Hawaii.

Back, E. L., \& Allen, L. H., 2000, Pitch control, Wood resin, and deresination, Danvers, MA: TAPPI Press.

Biermann, C. J., 1999, Handbook of Pulping and Papermaking, Second Edition, Academic Press, Oregon State University Corvallis, Oregon.

Blazey M. A., Grimsley, S. A., \& Chen, G. C., 2003, Optimizing a "Pitch Season" Forecast., TAPPI Spring Technical Conference Proceedings

Fischer, K. \& Messner, K., 1992, Reducing troublesome pitch in pulp mills by lipolytic enzymes, Tappi Journal, 75, 130-134.

Gurnagul, N., Ouchi, M. D., Dunlop-Jones, N., Sparkes, D. G., \& Wearing, J. T., 1992, Factors effecting the coefficient of friction of paper, Journal of Applied Polymer Science, 46, 805-814.

Irie, Y., Matsukura, M., Usui, M., \& Hata, K., 1990, Enzymatic pitch control in papermaking system, Tappi Papermakers Conference Proceedings, April 23-25.

Johansson, A., Fellers, C., Gundersson, D., \& Haugen, U., 1998, Paper friction - Influence of measurement conditions, TAPPI Journal, Vol. 85 No. 5, 175-183.

Kocurek, M.J. 1992.Pulpand Paper Manufacture, Paper Machine Operation, TAPPI PRESS, New York.

Sithole, B. B., \& Allen, L. H., 2003, A rapid method to measure glycerides in Wood Chips: A Facile Method to Assess the Age (Seasoning) of Wood Chips, TAPPI Journal Online Exclusive, Vol. 3 No. 10.

Thorn, I and Che On Au, 2009, Application of Wet-End Paper Chemistry, Second Edition, Springer Science, New York.

Vercoe, D., Stack, K., Blackman, A., \& Richardson, D., 2005, A mutlicomponent insight into the interactions leading to wood pitch deposition, Appita Journal Vol. 58 No. 3, 208-213.

Zhang, X., Renaud, S., \& Paice, M.G., The potential of laccase to remove extractives present in pulp and whitewater from TMP newsprint mills, Journal of Pulp and Paper Science Vol. 31 No. 4. 